УДК 373.5.016:82(100):373.5.091.33

DOI:

Іраїда Галелюк, викладач вищої категорії Дрогобицького коледжу нафти $і$ газу

Ольга Гарбич-Мошора, кандидат педагогічних наук, доиент кафедри інформатики та інформаційних систем Дрогобииького державного педагогічного університету імені Івана Франка

\title{
ІНТЕРАКТИВНІ МЕТОДИ НАВЧАННЯ НА ЗАНЯТТЯХ ЗАРУБІЖНОЇ ЛІТЕРАТУРИ
}

У статті розглянуто та проаналізовано інтерактивні методи навчання та їх роль $у$ досягненні високого інтелектуального розвитку студентів, оволодіння ними навичками саморозвитку особистості у процесі вивчення зарубіжної літератури. Подано коротку характеристику інтерактивних методів навчання: гра, робота в малих групах, дискусія. Теоретичний виклад теми проілюстровано конкретними прикладами з досвіду викладання зарубіжної літератури у Дрогобицькому коледжі нафти $і$ газу.

Ключові слова: інтерактивні методи навчання; зарубіжна література; творче мислення, креативне мислення.

Лim. 5.

Irayida Halelyuk, Lecturer of Higher Category Drohobych College of Oil and Gas Olha Harbych-Moshora, Ph.D.(Pedagogy), Associate Professor of the Informatics and Information Systems Department Drohobych Ivan Franko State Pedagogical University

\section{INTERACTIVE METHODS OF STUDYING AT FOREIGN LITERATURE LESSONS}

The article considers and analyzes the interactive methods of teaching and their role in achieving the high intellectual development of students, mastering them with the skills of self-development of the individual, self-improvement, expansion of their cognitive capabilities, gradual deprived of a complex of inferiority, the ability to think creatively and analytically, disclosing their organizational skills in the process of studying the foreign literature.

The pedagogical task of this subject is to create the harmonious, fully developed personality, who can competently express opinion. After all, literature is a model of behavior that stimulates not only emotions but also thoughts, stimulates their own spiritual, creative search.

The article gives a short description of interactive teaching methods: game dramatization and game competition, work in small groups, as well as discussion.

The game is a universal way of processing the impressions received from the surrounding world, which allows the student to identify the features of thinking and representation, its emotional, activity, develops the need for communication.

Work in groups helps students to lose their sense of loneliness, increases motivation, improves personal achievement, and creates a partnership between teachers and students who are working hard to achieve a common goal.

Our lives have different forms of discussion. Of particular importance are professional discussions, under the condition of proper conduct, a discussion that takes into account many factors: the psychology of conducting discussion, the logical and linguistic culture of discussion.

The theoretical coverage of the topic is illustrated by concrete examples from the teaching experience and used in foreign literature lessons at the Drogobych College of Oil and Gas.

Keywords: interactive methods of teaching; foreign literature; creative thinking; creative thinking.

П остановка проблеми. Розвиток українського суспільства значною мірою залежить від правильного вибору та активного запровадження моделі системи освіти, яка б, враховуючи особливості сучасності, могла забезпечити якісну підготовку конкурентоспроможних фахівців. У процесі становлення національної системи освіти на засадах їі гуманістичної спрямованості перед закладами освіти стоять відповідальні та перспективні завдання, одним з яких є створення оптимальних умов для розвитку пізнавального потенціалу фахівця, який повинен мати глибокі загальнонаукові та професійні знання, володіти стійкими професійними навичками та вміннями.

Метою державної Національної програми “Освіта” є виведення освіти в Україні на рівень розвинутих країн світу, що можливо лише за умов відходу від авторитарної педагогіки i впровадження сучасних педагогічних технологій. Саме цим зумовлена зараз увага педагогів, методистів до інновацій, де в умовах гуманізації 
навчання, особистісно-орієнтований підхід до навчання та виховання, трансформується у компетентісний підхід, але у центрі уваги залишається особистість студента [1]. Педагогічні інновації пов'язані сьогодні із застосуванням інтерактивних методів у навчальній та виховній діяльності педагога.

Молодь - це майбутнє нашої держави. Кожна молода людина має шанс для реалізації своїх здібностей і мрій. Саме таку можливість дає модернізація навчально-виховного процесу на сучасному етапі навчання, що в свою чергу сприяє формуванню та розвитку творчої особистості, що здатна використовувати отримані знання, спроможна повноцінно реалізуватись в подальшому житті й забезпечити інноваційний розвиток суспільства в цілому.

Аналіз останніх досліджень і публікацій, в яких започатковано розв'язання даної проблеми. Термін “інтерактивна педагогіка" вперше зустрічався в працях німецького дослідника Тансома Фріцема в 1975 році. Дослідження питань впровадження активної позиції особистості у процесі навчання на сучасному етапі займаються багато науковців, зокрема, В. Безпалько, М. Кларіна, П. Гальперіна. Методичні засади інтерактивної освіти, ефективність їі впливу на формування особистості грунтовно досліджено у працях І. Авдєєвої, О.Пометун, Н.Побірчинко, С.Сисоївої, О.Сидоренко, Г.Фреймена. Проте низка важливих питань, пов'язаних із упровадженням інтерактивних методів навчання в навчальний процес, потребує подальшого дослідження $[4,5]$.

Мета дослідження полягає у висвітленні питань щодо використання інтерактивних методів навчання на заняттях зарубіжної літератури у Дрогобицькому коледжі нафти і газу.

Виклад основного матеріалу дослідження. У ході нашого дослідження було визначено, що заняття з зарубіжної літератури - це витвір мистецтва, на якому викладачі експрементують, творчо підходять до викладення нового матеріалу, адже навчати літератури - це не тільки просто прочитання твору, вивчення біографічних знань про авторів, героїв і відомостей з теорії літератури, а й дати належний рівень морально-естетичного розвитку, мистецтва, культури мовлення та поведінки, легко, не нав'язливо для студентів, проте ефективно.

Для викладачів важливо підвищувати ефективність навчання, досягти високого інтелектуального розвитку студентів, оволодіння ними навичками саморозвитку особистості, допомогти розвивати власні думки, вміти робити узагальнення, дати волю фантазії, бути не тільки читачем, а й глядачем, режисером і співавтором твору. Педагогічне завдання цього предмету полягає у тому, щоб створити гармонійну, всебічно розвинену особистість, яка вміє грамотно висловити свою думку. Адже література - це модель поведінки, яка збуджує не лише емоції, а й думку, стимулює власний духовний, творчий пошук. Література - це мистецтво, мистецтво слова, яке торкається душі [3].

Сучасне заняття зарубіжної літератури вимагає переосмислення пріоритету методів, прийомів та видів навчальної діяльності, розширення їхньої методичної палітри. Одним зі шляхів є впровадження в педагогічну практику інтерактивних методів навчання, як безпосередньо самих, так і з використанням інформаційно комунікаційних технологій. Використання інтерактивних методів на заняттях створює атмосферу комфортних умов навчання, яка сприяє співробітництву між викладачами та студентами, надає можливість якнайповніше реалізувати особистісно-зорієнтоване навчання 3 урахуванням міжпредметних зв'язків [3]. У ході інтерактивного навчання студент виробляє навички самовдосконалення, розширює свої пізнавальні можливості, поступово позбавляється комплексу неповноцінності, відкриває самого себе, вчиться творчо й аналітично мислити, розкриває свої організаторські здібності. Позитивним у використанні інтерактивного навчання $\epsilon$ партнерство між викладачами та студентами, які пліч о пліч працюють над досягнення спільної мети - здобуття нових знань та вмінь проявляти себе особистісно, а певною мірою успішності такої взаємодії, є отриманні знання та навички студента.

Питання про використання інтерактивних технологій на занятті зарубіжної літератури на даний час є доволі дискусійним. Оскільки, інтерактивне навчання є вимогою сучасності, бо кожна людина прагне модерного, чогось нового, цього й вимагає сьогодення. 3 іншого боку, слід знати міру у використанні інтерактивних методів на занятті, щоб не загубити мету і завдання заняття.

В ході нашого дослідження пропонуємо розглянути такі інтерактивні методи, які практично використовуються на заняттях з зарубіжної літератури в академічних групах 18-M1-Тр (механіка та транспортування), 18-А-1 (автоматизація), 18-Е-1(експлуатація), 18-Б1(буріння) в Дрогобицькому коледжі нафти і газу: гра, дискусія, робота в малих групах.

Одним із ефективних способів залучення 


\section{ІНТЕРАКТИВНІ МЕТОДИ НАВЧАННЯНА ЗАНЯТТЯХЗАРУБІЖНОЇЛТТРАТУРИ}

студентів до читання творів згідно програми та додаткової літератури є прийом “навчання в грі”, що впливає і на пізнавальну, і на емоційноособистісну сферу студентів.

В. Сухомлинський писав: “... у грі розкривається перед дітьми світ, творчі можливості особистості. Без гри немає і не може бути повноцінного дитячого розвитку. Гра - це величезне світле вікно, через яке в духовний світ дитини вливається життєдайний потік уявлень, понять про навколишній світ" [5]. Гру він порівнював з іскоркою, що запалює вогник допитливості і любові до знань.

І це справді так, оскільки гра має надзвичайно багато навчальних і виховних можливостей:

- Активізує, урізноманітнює навчальний процес, знімає напруженість.

- Забезпечує розумовий, світоглядний i особистісний розвиток кожного студента, що в свою чергу сприяє зміні рівнів активності учасників гри: від репродуктивного через пошуковий до творчого.

- Впливає на формування особистості: студенти вчаться виборювати перемогу прагнучи до успіху, досягають поставленої мети, вимогливо ставляться до себе, бачать перспективу власного зростання й усвідомлюють потребу самовдосконалення.

- Спонукає студенів до інтелектуальної роботи.

- Сприяє вихованню в студентів товариської й колективної праці над поставленим завданням, поглиблює комунікабельність [5].

Гра на занятті спонукає думати, аналізувати й швидко реагування на поставленні перед ними завдання, підшуковувати правильні відповіді на запитання, що постають, а також активізує мислення й розвиває кмітливість. Знання, здобуті таким чином, міцніші, ніж знання, одержані в готовому вигляді.

У ході нашого дослідження було визначено, що гра на занятті зарубіжної літератури виконує ефективно свої функції, якщо вона відповідає певним умовам:

- Застосовується в різноманітних формах при чому дає можливість студентам дати волю своїй фантазії: бути режисером і співавтором літературного твору.

- Узгоджується $з$ іншими дидактичними засобами.

- Забезпечує всебічний розвиток особистості.

- Цікава за змістом та формою і відповідає віковим особливостям студентів.

- Стимулює мотивацію навчання.

- Організовується так, щоб студенти максимально використовували здобуті знання й змогли проаналізувати поставленні перед ними завдання.

Форм роботи, під час навчання у грі, є багато, але найчастіше на наших заняттях використовуюся гра драматизація та гра конкурс “Твір очима художника”. Темою гри драматизації може бути драматичний чи літературний твір або інсценізація епічного твору.

Як показує практика найчастіше студенти полюбляють брати інтерв'ю у письменника чи поета. Ось фрагмент зустрічі у літературній вітальні:

Журналіст: “Дозвольте запитати Вас, як ви ставитесь до слів Віктора Гюго стосовно Вас: “... перший серед великих, один 3 найкращих серед вибраних...?"

Оноре де Бальзак жартівливо: “Давно зрозуміло, що я геній. I його слова це підтверджують"

Журналіст: “Які плани в батьків були на Вас? Ким хотіли Вас бачити?”

Оноре де Бальзак: “Тільки не літератором. (посміхається) Мріяли про професію юриста для мене".

Що ж до гри конкурсу “Твір очима художника”. Вивчаючи твір, пропонується студентам малювати ілюстрації які коротко зображають зміст розділу чи цілого твору при цьому пропонується захищати свої творчі шедеври. Під час захисту слід вказати:

- Аргументуйте чому саме даний епізод відтворено у вашим малюнках?

- Чим вразив вас даний герой, які притаманні для нього риси, вчинки?

- Чому саме такий ракурс героя Ви уявили?

Вивчаючи роман "Червоне та чорне" Стендаля, пропоную студентам спробувати себе в ролі дизайнера, який повинен створити успішну рекламу книги за допомогою серії малюнків до кожної частини, які умовно їх можна поділити на чотири періоди. Де можна зобразити пана Реналя, власника цвяхової фабрики - типовим, пихатим дворянином з комічною зовнішністю, вайлуватим виглядом і т.д.

Одним із важливих засобів пізнавальної діяльності, що в подальшому сприяє розвитку критичного та креативного мислення, дає можливість визначити власну позицію, формує навички аргументації, вчить відстоювати свою думку, своє бачення певної ситуації, поглиблює знання з обговорюваної проблеми - дискусія [4]. Аби дискусія була вдалою і результати були високими, викладач повинен самостійно обдумати тему, яка має бути сформульована проблемно, щоб підходи до іiі висвітлення були різними, яка 
буде цікавити студентів [2]. Одним із важливих етапів є план в якому наявні питання для обговорення, які даються напередодні дискусії, щоб студенти змогли підготуватись до обговорення: попрацювати 3 літературою, інтернетом, підготувати собі попередні нотатки. Викладач може також підготувати до дискусії деякий роздатковий матеріал: портрети письменників, ілюстрації до твору, речі про які йдеться в творах (кумедна шапка головного героя, дзеркальце яке любила героїня).

В ході дискусії слід звертати увагу на те, щоб обговорення не перетворилось у гарячу суперечку, але й не потрібно гасити усі прояви емоцій. Необхідно ставти конкретні запитання, щоб пробудити обговорення, й абстрактні, щоб остудити запал активних студентів. Не варто забувати в ході дискусії про заключну частину підсумки, які повинні зробити самі студенти.

Вивчаючи твори Джека Лондона, в якого майже весь шлях відображено в його працях, ми iз студентами дискутуємо над такими питаннями:

1. Який твір, написаний молодим Джеком Лондоном, дав усім зрозуміти, щзо в літературу прийшов новий митець, за яких життєвих умов і обставин ие сталося?

2. Звідки черпав матеріал Джек Лондон для своїх творів?

3. Якими рисами характеру володів головний герой твору? Чому автор так його зобразив?

Під час вивчення твору О. Уайльда "Портрет Доріана Грея проводиться заняття у вигляді дискусії на основі таких питань:

1. Яка мрія з'явилася у Доріана, коли він побачив вперше свій портрет?

2. Чому почуття радості у героя замінюється страхом коли він побачив портрет?

3. Чим стає для Доріана його портрет?

4. Якими почуттями керувався Доріан, коли вирішив покінчити з портретом? Чи можна стверджувати, щьо Доріан вбиває самого себе?

5. Якби ви були автором иього твору, які б зміни ви внесли в цей роман?

6. Які моральні проблеми, актуальні для сучасного читача, піднято в романі?

7. Чи є сторінки в романі, що стали для вас повчальними або особливими?

Робота в малих групах допомагає студентам набути навичок спілкування й співпраці. Це один iз найбільш ефективних методів, адже за організації групової роботи відбувається обмін думками, результатом якого $є$ оптимальне спільне вирішення поставленої проблеми. Оскільки в академічних групах від 16 до 20 студентів їх легко можна поділити на творчі групи на етапі ознайомлення 3 новим матеріалом, що забезпечить інтенсивний пошук найцікавішого матеріалу, добір гострих проблемних питань.

Група “Літературний ексклюзив"

Ця група шукає виняткову інформацію, невідомі факти біографії письменника, складної долі видання творів, відомості про ще не надруковані матеріали.

Група “Авторська лабораторія"

В дану групу входять талановиті студенти, що мають творче мислення, художній смак, добре володіють художнім стилем мовлення. Їм даються завдання доповнити авторський текст, написати свою версію твору на визначену тематику, зробити власний портрет - опис героя, вмотивувати його вчинки з огляду на сучасність.

Група "Експертна група"

Студенти цієї групи здійснюють контроль за регламентом, слідкують за подачею оригінальних ідей розкриттям проблем, допомагають викладачеві в об'єктивному оцінюванні, підводять підсумок.

Група “Літературний художник"

Студенти цієї групи за допомогою серії малюнків, нарисів, графіті коротко зображають зміст розділу чи цілого твору.

Отже, упровадження інтерактивних методів навчання сприяє формуванню у студентів пізнавального інтересу до вивчення зарубіжної літератури, що в свою чергу дозволяє викладачу враховувати особливості розвитку творчих здібностей студентів, адже інтерактивні методи навчання активізують творчий потенціал й підвищують якість засвоєння х знань, забезпечують практичну й творчу підготовку з предмету.

Iз носія готових знань, викладач перетворюється в організатора пізнавальної діяльності студенів, а останні - стають рівноправними суб'єктами в навчанні. Водночас створюється та реалізується модель творчої особистості, яка не лише володіє навичками спілкування, а й вміє самостійно працювати над розвитком власного інтелекту, культури й моралі, виявляє свій творчий потенціал, що є основою успішного подальшого професійного становлення особистості.

Розглянуті нами методи мають високу ступінь універсальності, а прийняття рішень може здійснюватись в умовах багатокритеріальності, а також із врахуванням властивостей, що не мають кількісного виразу. Важливо, що при їх застосуванні рішення приймається не 3 "чистого листа”, а на основі ретельного аналізу позитивних i негативних наслідків. При цьому практично 
виключається можливість прийняття необдуманих вольових, інтуїтивних або випадкових рішень.

\section{ЛІТЕРАТУРА}

1. Вища освіта україни і Болонський процес: Навчальний посібник / За редакцією В.Г.Кременя. Тернопіль: Навчальна книга - Богдан, 2004. - 384c.

2. Інтерактивні технології навчання// режим доступу http://www.refotext.com/referat-text-16587-1.html.

3. Мельник А.О. Ігри на уроках зарубіжної літератури. Всесвітня література в середніх навчальних закладах України. - 2011. - №6.

4. Сиротенко Г.О. Сучасний урок: інтерактивні технології навчання. - Х.: Основа, 2013. -220 с.

5. Щербань П.М. Навчально-педагогічні ігри: Навчальний посібник. - К.: Вища школа, 2003. - 240 с.

\section{REFERENCES}

1. Kremen, V. G. (Ed.). (2004). Vyshcha osvita ukrainyi
Bolonskyi protses: Navchalnyi posibnyk [Higher Education in Ukraine and the Bologna Process: Training Manual]. Ternopil: Educational book - Bogdan, 384 p. [in Ukrainian].

2. Interaktyvni tekhnolohii navchannia [Interactive Learning Technologies]. Available at: http:// www.refotext.com/referat-text-16587-1.html. [in Ukrainian].

3. Melnyk, A. O. (2011). Ihry na urokakh zarubizhnoi literatury [Games in the lessons of foreign literature]. World Literature in Secondary Schools of Ukraine, No. 6. [in Ukrainian].

4. Syrotenko, G. O. (2013). Suchasnyi urok: interaktyvni tekhnolohii navchannia [Contemporary Lesson: Interactive Learning Technologies]. Kharkiv: Osnova, 220 p. [in Ukrainian]

5. Shcherban, P. M. (2003). Navchalno-pedahohichni ihry: Navchalnyi posibnyk [Teaching and educational games: Tutorial]. Kyiv: Higher school, 240 p. [in Ukrainian].

Стаття надійшла до редакції 27.11.2018

\section{УДК 78.071.2(477) \\ DOI:}

Стефанія Пінчак, старший викладач кафедри народних музичних інструментів та вокалу Інституту музичного мистеитвва Дрогобиџького державного педагогічного університету імені Івана Франка

\section{ТВОРЧА ДІЯЛЬНІСТЬ КОРИФЕЯ БАНДУРНОГО МИСТЕЦТВА ГНАТА ХОТКЕВИЧА}

У статті висвітлюються багатогранні напрялки творчої діяльності Гната Хоткевича як теоретикадослідника, практика-виконавия, педагога, композитора кіния XIX-першої половини XX століття.

Визначено роль Гната Хоткевича як фундатора професійної бандурної школи. Він є автором перших науково-методичних розробок, першого професійного репертуару для бандури. Ознаменував створення нового напрямку колективної форми бандурного виконавства, трактування бандури як акомпануючого, так $i$ самостійного кониертного інструменту.

Досліджено, що педагогічна та творча спадщина мития є глибоко національною за змістом та має значний внесок у розвиток музичної освіти та бандурного мистецтвва.

Ключові слова: кобзарське мистецтво; виконавець; бандура; віртуоз; репертуар; педагогічна спадщина.

Jim. 7.

Stefaniya Pinchak, Senior Lecturer of the Folk Musical Instruments and Vocal Department Institute of Musical Art Drohobych Ivan Franko State Pedagogical University

\section{HNAT HOTKEVYCH AS A PHENOMENON MULTIPLAYER PERSONALITY}

The article reveals Hnat Khotkevych's heritage in a variety of creative realms: as a theorist and a researcher, as a practical implementer, as an educator, and as a composer active in the period of late 19th-early 20th centuries.

The author has ascertained Hnat Khotkevych's role as a founding father of a professional bandura music school. Khotkevych was the author of the early academic and methodological blueprints and of the first professional bandura repertoire. He inaugurated the creation of a new direction of collective form of bandura performance and upgraded the status of bandura as both an accompanying and an independent instrument.

The study shows that Khotkevych's heritage as an educator and as a creative artist is, in its contents, of deeply national essence and character and contributes massively into the development of musical education and the art of bandura.

The article focuses on the analysis of creative heritage and academic researches undertaken by Hnat Khotkevych, a phenomenally gifted artist and a genuinely multifaceted personality. 